Departamento de Genética, Universidade Federal de Pernambuco (UFPE), Av. da Engenharia, s/n. CEP 50740-600, Recife, PE, Brazil

2 Embrapa Algodão, Campina Grande, PB, Brazil

* autor correspondente $\square$ santelmovasconcelos@gmail.com

\title{
Accessing genetic diversity levels of Brazilian genotypes of castor with AFLP and ISSR markers
}

\author{
Acessando os niveis de diversidade genética de genótipos \\ brasileiros de mamona com marcadores AFLP e ISSR
}

Santelmo Vasconcelos ${ }^{1 *}$, Alberto Vinicius Casimiro Onofre' ${ }^{1}$ Máira Milani²,

Ana Maria Benko-Iseppon ${ }^{1}$, Ana Christina Brasileiro-Vidal

\begin{abstract}
Castor (Ricinus communis L.), an important oilseed crop for the production of biofuels and high quality lubricants, has a long history of cultivation worldwide. However, very little is known about the genetic diversity of cultivars adapted to the semi-arid conditions of Northeastern Brazil, a strategic area for castor cultivation. Aiming to provide new approaches to select dominant markers for genetic diversity analysis among castor accessions from a Brazilian germplasm bank, we have tested 21 AFLP primer combinations and 16 ISSR primers with 27 genotypes from a Brazilian germplasm bank. PIC, MI and RP values were calculated for both marker systems and a strong correlation was observed among these parameters. Therefore, due to a higher degree of variation, primers could be better selected taking into account the RP values, which ranged from 0.231 to 18.231 (AFLP) and from 1.630 to 9.556 (ISSR). Dissimilarity values ranged from 0.189 to 0.504 in the combined analysis (AFLP + ISSR), with genotypes grouping into four main clusters, although without any evidence of genetic structuration $\left(\mathrm{F}_{\mathrm{st}}=0.108\right)$. The successful association between genotypes and specific marks highlighted the great potential of AFLP and ISSR markers to access the variability within the species. Additionally, by describing new

RESUMO: Visando descrever novas abordagens para a seleção de marcadores dominantes para análises de diversidade genética entre acessos de mamona, foram aplicadas 21 combinações de marcadores AFLP e 16 marcadores ISSR utilizando 27 genótipos de um banco de germoplasma brasileiro. Valores de PIC, MI e RP foram calculados para ambos os sistemas de marcadores e foi observada uma forte correlação entre tais parâmetros. Assim, devido a um maior grau de variação, os primers puderam ser melhor selecionados por meio dos valores de RP, os quais foram observados entre 0,231 e 18,231 (AFLP) e entre 1,630 e 9,556 (ISSR). Os valores de dissimilaridade variaram entre 0,189 a 0,504 na análise combinada (AFLP + ISSR), onde os genótipos foram divididos em quatro grupos principais, embora sem haver evidência de estruturação genética $(F s t=0,108)$. A associação bem sucedida entre genótipos e marcas específicas evidenciou o grande potencial dos marcadores AFLP e ISSR para acessar a variabilidade dentro da espécie. Adicionalmente, por meio da descrição de novos marcadores polimórficos para a diferenciação entre genótipos, o presente trabalho traz uma grande contribuição para o direcionamento de cruzamentos entre acessos com características de interesse.
\end{abstract} polymorphic markers for genotype differentiation, we provide an important contribution to guide crosses between accessions with traits of interest.

KEYWORDS: Ricinus communis, DNA fingerprinting, dominant markers, germplasm.
PALAVRAS-CHAVE: Ricinus communis, DNA fingerprinting, marcadores dominantes, germplasma. 


\section{Introduction}

Euphorbiaceae is one of the most diverse and numerous plant families, including species of a worldwide economic importance such as castor (Ricinus communis L.), physic nut (Jatropha curcas L.), candle nut (Aleurites moluccana (L.) Willd.), cassava (Manihot esculenta Crantz) and rubber tree (Hevea brasiliensis (Willd. ex A.Juss.) Müll.Arg.). Castor is one of the most important non-edible oil seed crops and has gained a great visibility in the mid-2000s due to its potential use as a renewable source of energy (SEVERINO et al., 2012). Several unique characteristics of the castor oil have made this crop an essential raw material for different industry sectors, although with a major importance for the production of paints and lubricants (OGUNNIYI, 2006).

Even with major recent advances towards the genome analysis of castor, which includes the publication of its draft genome sequence by Chan et al. (2010), only relatively few papers have brought genetic diversity evaluations of germplasm banks with molecular markers (ANJANI, 2012; VASCONCELOS et al., 2012). According to Severino et al. (2012), the number of accessions that were genetically characterized still is very low, taking into account a total of 11,300 accessions of the main germplasm banks from 11 countries.

Curiously, the use of widely spread and low-cost anonymous markers such as RAPD (random amplified polymorphic DNA) and ISSR (inter-simple sequence repeat) in genetic diversity analyses is still scarce (GAJERA et al., 2010; MACHADO et al., 2013). Even the powerful and reliable marker system described by Vos et al. (1995), the AFLP (amplified fragment length polymorphism), was poorly used to describe the extant polymorphism in the species (ALLAN et al., 2008; PECINA-QUINTERO et al., 2013). In contrast, for another oil-bearing species that belongs to the family Euphorbiaceae, namely the physic nut, several genetic diversity analyses with dominant markers have been published in recent years (TATIKONDA et al., 2009; GRATIVOL et al., 2011; PAMIDIMARRI; REDDY, 2014).

On the other hand, co-dominant markers as SSRs (simple sequence repeats) and SNPs (single nucleotide polymorphisms), which are more expensive to be established, although once developed they might become more cost-effective due to the aggregated information about heterozygosity levels (WEISING et al., 2005; NYBOM; WEISING; ROTTER, 2014), have been successfully applied in genetic diversity analyses among and within castor germplasm banks (ALLAN et al., 2008; FOSTER et al., 2010). However, still there is a need for selection of robust molecular markers able to distinguish accessions and/or associated to phenotypic traits of interest such as oil production, resistance to abiotic stress and pathogens (SEVERINO et al., 2012).

Therefore, in the present work, we have tested and described new polymorphic and valuable AFLP and ISSR markers for genetic diversity analyses, using 27 genotypes with different traits of interest from the germplasm bank of the Brazilian Agricultural Research Corporation (Embrapa), the $5^{\text {th }}$ in number of accessions worldwide (SEVERINO et al., 2012). Additionally, to reinforce the utility of the sampled markers, we have also tested some parameters aiming for a better primer selection in future evaluations.

\section{Materials and Methods}

The analyzed material was provided by Embrapa Algodão (Campina Grande, Brazil) and consisted of 27 castor genotypes (Table 1) adapted to semiarid conditions. DNA extraction followed the CTAB protocol I described by Weising et al. (2005).

For AFLP markers amplification, the Invitrogen kits AFLP Analysis System (10483-022) and AFLP Starter Primer Kit (10482-016) were used, following the protocol recommended by the manufacturer, which consisted of the following steps: (1) DNA enzymatic restriction with EcoRI and MseI; (2) ligation of adapters; (3) pre-amplification reaction; and (4) selective amplification with 21 out of 64 primer combinations that were previously tested by Vasconcelos et al. (2012) for genetic diversity characterization among castor genotypes (Table 2). Following the second amplification round, the separation of the generated DNA fragments was carried out in $6 \%$ denaturing polyacrylamide gel electrophoresis, as described by Vos et al. (1995).

The ISSR markers were amplified by following the protocol described by Bornet and Branchard (2001) with some modifications. From the 60 primers of the UBC set No. 9 (University of British Columbia) tested by Vasconcelos et al. (2012), 16 were selected (Table 3). All PCR solutions contained $0.8 \mathrm{U} \mathrm{Taq}$ polymerase (Fermentas), $1 \times$ Taq buffer with $\mathrm{KCl}$, $2.5 \mathrm{mM} \mathrm{MgCl}, 1 \mathrm{mM}$ dNTP-mix, $50 \mu \mathrm{m}$ primer and $25 \mathrm{ng}$ genomic DNA. PCRs were performed in a Techne TC-412 thermocycler with the amplification conditions consisting of 1 min initial denaturation step $\left(94^{\circ} \mathrm{C}\right)$, followed by 35 cycles of: (1) $30 \mathrm{~s}$ at $94^{\circ} \mathrm{C}$ denaturation, (2) $45 \mathrm{~s}$ at specific annealing temperature (Table 3) and (3) 2 min at $72{ }^{\circ} \mathrm{C}$ extension; the reactions were completed by a final extension step of $7 \mathrm{~min}$ at $72{ }^{\circ} \mathrm{C}$. PCR products were separated by electrophoresis using a $1.8 \%$ agarose gel that was prepared with $0.5 \mu \mathrm{g} / \mathrm{mL}$ ethidium bromide.

The genotyping was conducted by constructing a binary matrix that was based on the visual criterion of presence (1) and absence $(0)$ of clear amplified DNA fragments. Information about polymorphism levels followed the criterion proposed by Ott (1992), in which the scored bands for either less than $5 \%$ or more than $95 \%$ of the accessions are considered as monomorphic.

The discriminatory power of AFLP primer combinations and ISSR primers were determined by using three parameters: (1) polymorphism information content (PIC), (2) marker index (MI) and resolving power (RP). PIC values were obtained according to Roldan-Ruiz et al. (2000):

$\mathrm{PIC}_{\mathrm{i}}=2 \mathrm{f}_{\mathrm{i}}\left(1-\mathrm{f}_{\mathrm{i}}\right)$

where $\mathrm{PIC}_{\mathrm{i}}$ is the polymorphism information content of marker $i, f_{i}$ the frequency of the marker fragments that were present and $1-f_{i}$ the frequency of absent marker fragments. Subsequently, the average PIC was obtained for each primer 
Table 1. Castor accessions from the germplasm bank of Embrapa Algodão (Campina Grande, Brazil) for molecular characterization by DNA fingerprinting with AFLP and ISSR markers.

\begin{tabular}{|c|c|c|c|c|c|}
\hline No. & Accessions & $\begin{array}{c}\text { Oilseed } \\
\text { content }(\%)^{1}\end{array}$ & Seed mass $(g)^{1}$ & Origin & Main features \\
\hline 1 & BRA 3182 & 45.8 & 1.40 & $\begin{array}{l}\text { Wild lineage from Bahia } \\
\text { (Brazil) }\end{array}$ & $\begin{array}{l}\text { Purple plant, without blooming, average } \\
\text { stature and average cycle }\end{array}$ \\
\hline 2 & BRA 3271 & 43.2 & 1.32 & $\begin{array}{l}\text { Wild lineage from Bahia } \\
\text { (Brazil) }\end{array}$ & $\begin{array}{c}\text { Semi-dehiscent fruits, green leaves, brown } \\
\text { stem and average stature }\end{array}$ \\
\hline 3 & BRA 3361 & 43.8 & 1.20 & $\begin{array}{l}\text { Wild lineage from Bahia } \\
\text { (Brazil) }\end{array}$ & $\begin{array}{l}\text { Dehiscent fruits, green plant and without } \\
\text { blooming }\end{array}$ \\
\hline 4 & BRA 6548 & 46.8 & 3.48 & $\begin{array}{l}\text { Wild lineage from } \\
\text { Paraíba (Brazil) }\end{array}$ & $\begin{array}{l}\text { Semi-dehiscent fruits, green plant, without } \\
\text { blooming and average stature }\end{array}$ \\
\hline 5 & BRA 8745 & 46.6 & 1.48 & $\begin{array}{l}\text { Wild lineage from Bahia } \\
\text { (Brazil) }\end{array}$ & $\begin{array}{l}\text { Semi-dehiscent fruits, green plant, without } \\
\text { blooming and average stature }\end{array}$ \\
\hline 6 & BRS Energia & 50.5 & 6.89 & Embrapa cultivar & Indehiscent fruits, green plant and short cycle \\
\hline 7 & BRS Gabriela & 50.0 & 11.06 & Embrapa cultivar ${ }^{2}$ & $\begin{array}{l}\text { Indehiscent fruits, short stature and short } \\
\text { cycle }\end{array}$ \\
\hline 8 & BRS Nordestina & 45.5 & 3.03 & Embrapa cultivar & $\begin{array}{c}\text { Semi-dehiscent fruits, green plant, average } \\
\text { stature and average cycle }\end{array}$ \\
\hline 9 & BRS Paraguaçu & 50.6 & 18.19 & Embrapa cultivar & $\begin{array}{c}\text { Semi-dehiscent fruits, purple plant, average } \\
\text { stature and average cycle }\end{array}$ \\
\hline 10 & CNPAM 93-168 & 47.3 & 13.88 & Embrapa breeding line & $\begin{array}{c}\text { Selection of highly productive lines and } \\
\text { average stature }\end{array}$ \\
\hline 11 & CNPAM 2000-9 & 52.3 & 15.99 & Embrapa breeding line & $\begin{array}{c}\text { Selection of highly productive lines and } \\
\text { average stature }\end{array}$ \\
\hline 12 & CNPAM 2000-48 & 48.8 & 7.40 & Embrapa breeding line & $\begin{array}{c}\text { Selection of highly productive lines and } \\
\text { average stature }\end{array}$ \\
\hline 13 & CNPAM 2001-5 & 52.5 & 9.44 & Embrapa breeding line & $\begin{array}{c}\text { Selection of lines with indehiscent fruits, short } \\
\text { stature and short cycle }\end{array}$ \\
\hline 14 & CNPAM 2001-48 & 49.0 & 11.28 & Embrapa breeding line ${ }^{2}$ & $\begin{array}{c}\text { Selection of lines with indehiscent fruits, short } \\
\text { stature and short cycle }\end{array}$ \\
\hline 15 & CNPAM 2001-50 & 51.3 & 11.73 & Embrapa breeding line $\mathrm{e}^{2}$ & $\begin{array}{c}\text { Selection of lines with indehiscent fruits, short } \\
\text { stature and short cycle }\end{array}$ \\
\hline 16 & CNPAM 2001-63 & 51.0 & 5.18 & Embrapa breeding line & $\begin{array}{c}\text { Selection of highly productive lines and } \\
\text { average stature }\end{array}$ \\
\hline 17 & CNPAM 2001-70 & 48.4 & 4.87 & Embrapa breeding line & $\begin{array}{c}\text { Selection of highly productive lines and } \\
\text { average stature }\end{array}$ \\
\hline 18 & CSRD-2 & 46.2 & 7.60 & Lineage from Costa Rica & Green plant, waxy and dwarf plant \\
\hline 19 & Epaba 81 & 43.6 & 2.13 & Epaba cultivar & $\begin{array}{c}\text { Dehiscent fruits, average stature and long } \\
\text { cycle }\end{array}$ \\
\hline 20 & IAC 80 & 43.2 & 8.51 & IAC cultivar ${ }^{3}$ & Dehiscent fruits and average stature \\
\hline 21 & IAC 2028 & 49.4 & 9.24 & IAC cultivar ${ }^{3}$ & $\begin{array}{l}\text { Indehiscent fruits, average stature and } \\
\text { average cycle }\end{array}$ \\
\hline 22 & IAC Guarani & 46.4 & 9.57 & IAC cultivar ${ }^{3}$ & Indehiscent fruit and average stature \\
\hline 23 & Mirante-10 & 50.0 & 7.87 & $\begin{array}{l}\text { Cultivar from Mirante } \\
\text { Sementes da Bahia }\end{array}$ & Indehiscent fruits, middle stature, long cycle \\
\hline 24 & Sipeal 7 & 44.8 & 1.84 & Ipeal cultivar & $\begin{array}{l}\text { Dehiscent fruits, average stature and long } \\
\text { cycle }\end{array}$ \\
\hline 25 & Sipeal 20 & 39.7 & 1.76 & Ipeal cultivar & $\begin{array}{l}\text { Dehiscent fruits, average stature and long } \\
\text { cycle }\end{array}$ \\
\hline 26 & Sipeal 21 & 37.6 & 1.89 & Ipeal cultivar & $\begin{array}{l}\text { Dehiscent fruits, average stature and long } \\
\text { cycle }\end{array}$ \\
\hline 27 & $\begin{array}{c}\text { SM5 } \\
\text { Pernambucana }\end{array}$ & 47.5 & 15.08 & Embrapa breeding line & $\begin{array}{c}\text { Selection of highly productive lines and } \\
\text { average stature }\end{array}$ \\
\hline
\end{tabular}

${ }^{1}$ Data provided by Embrapa Algodão. ${ }^{2}$ Selection of individual plants from a cross between BRS Nordestina and BRS Paraguaçu, considering low height and precocity. ${ }^{3}$ IAC: Instituto Agronômico de Campinas, Campinas - SP, Brazil. 
Table 2. Primer combinations used during AFLP selective amplification among 27 castor genotypes, indicating their respective information and polymorphism levels.

\begin{tabular}{|c|c|c|c|c|c|c|c|c|c|c|c|}
\hline $\begin{array}{c}\text { Primer } \\
\text { Combinations }\end{array}$ & $\mathbf{T N F}^{1}$ & $\mathbf{N P F}^{2}$ & $f_{p}(\%)^{3}$ & $\mathbf{N U F}^{4}$ & $\mathrm{NRF}^{5}$ & $\mathrm{NFF}^{6}$ & $\mathbf{N C F}^{7}$ & NSF $^{8}$ & PIC $^{9}$ & $\mathbf{M I}^{10}$ & $\mathbf{R P}^{11}$ \\
\hline E-AAC + M-CAA & 25 & 16 & 64.0 & 2 & 1 & 7 & 8 & $\mathbf{0}$ & 0.195 & 3.809 & 6.590 \\
\hline E-AAC + M-CAT & 46 & 18 & 39.1 & 2 & 10 & 7 & 1 & 3 & 0.121 & 1.445 & 7.353 \\
\hline E-AAG + M-CAA & 23 & 13 & 56.5 & 1 & 3 & 5 & 5 & $\mathbf{0}$ & 0.162 & 2.786 & 5.185 \\
\hline E-AAG + M-CAT & 29 & 12 & 41.4 & $\mathbf{0}$ & 6 & 5 & 1 & 1 & 0.128 & 1.614 & 5.000 \\
\hline E-AAG + M-CTA & 35 & 16 & 45.7 & 3 & 10 & 3 & 3 & $\mathbf{0}$ & 0.109 & 1.518 & 4.675 \\
\hline E-AAG + M-CTC & 28 & 6 & 21.4 & $\mathbf{0}$ & 1 & 5 & $\mathbf{0}$ & 1 & 0.086 & 0.562 & 3.684 \\
\hline E-AAG + M-CTT & 39 & 14 & 35.9 & 2 & 4 & 7 & 3 & $\mathbf{0}$ & 0.121 & 1.328 & 6.909 \\
\hline E-ACA + M-CAC & 8 & 1 & 12.5 & $\mathbf{0}$ & $\mathbf{0}$ & $\mathbf{0}$ & 1 & $\mathbf{0}$ & 0.026 & 0.097 & 0.231 \\
\hline E-ACA + M-CAT & 20 & 6 & 30.0 & $\mathbf{0}$ & 3 & 2 & 1 & 2 & 0.080 & 0.732 & 2.228 \\
\hline E-ACC + M-CAA & 29 & 12 & 41.4 & 2 & 5 & 6 & 1 & 2 & 0.153 & 1.929 & 6.689 \\
\hline E-ACC + M-CAT & 20 & 3 & 15.0 & $\mathbf{0}$ & $\mathbf{0}$ & $\mathbf{0}$ & 3 & $\mathbf{0}$ & 0.021 & 0.094 & 0.444 \\
\hline E-ACC + M-CTA & 16 & 7 & 43.8 & $\mathbf{0}$ & 1 & 4 & 2 & $\mathbf{0}$ & 0.143 & 1.902 & 3.185 \\
\hline E-ACG + M-CAA & 33 & 19 & 57.6 & 5 & 3 & 14 & 2 & 2 & 0.226 & 3.958 & 10.754 \\
\hline E-ACG + M-CAC & 63 & 41 & 65.1 & 15 & 31 & 6 & 4 & 5 & 0.172 & 3.412 & 12.741 \\
\hline E-ACG + M-CTT & 17 & 8 & 47.1 & $\mathbf{0}$ & 4 & 2 & 2 & 2 & 0.142 & 2.032 & 3.259 \\
\hline E-ACT + M-CAC & 20 & 1 & 5.0 & 2 & 1 & $\mathbf{0}$ & $\mathbf{0}$ & $\mathbf{0}$ & 0.014 & 0.021 & 0.296 \\
\hline E-ACT + M-CAG & 20 & 1 & 5.0 & 2 & $\mathbf{0}$ & 1 & $\mathbf{0}$ & 1 & 0.031 & 0.046 & 0.764 \\
\hline E-ACT + M-CTA & 60 & 36 & 60.0 & 3 & 13 & 21 & 2 & 1 & 0.210 & 3.835 & 18.231 \\
\hline E-ACT + M-CTT & 34 & 11 & 32.4 & 3 & 5 & 4 & 2 & 4 & 0.105 & 1.039 & 4.709 \\
\hline E-AGG + M-CAA & 28 & 7 & 25.0 & $\mathbf{0}$ & 2 & 4 & 1 & 5 & 0.104 & 0.791 & 4.370 \\
\hline E-AGG + M-CTA & 47 & 30 & 63.8 & 3 & 15 & 14 & 1 & 1 & 0.200 & 3.895 & 12.889 \\
\hline Total & 640 & 278 & 43.4 & 45 & 118 & 117 & 43 & 30 & - & - & - \\
\hline
\end{tabular}

${ }^{1}$ Total number of fragments. ${ }^{2}$ Number of polymorphic fragments. ${ }^{3}$ Frequency of polymorphic fragments. ${ }^{4}$ Number of unique fragments. ${ }^{5}$ Number of rare fragments. ${ }^{6}$ Number of frequent fragments. ${ }^{7}$ Number of common fragments. ${ }^{8}$ Number of shared fragments. ${ }^{9}$ Polymorphism information content. ${ }^{10}$ Marker index. ${ }^{11}$ Resolving power.

combination/single primer. MI values were obtained as described by Varshney et al. (2007):

$\mathrm{MI}=\mathrm{PIC} \times \mathrm{n} \times \mathrm{n}_{\mathrm{p}} \times\left(\mathrm{n}_{\mathrm{p}}+\mathrm{n}_{\mathrm{m}}\right)^{-1}$

where $\mathrm{n}$ is the average number of fragments per primer, $\mathrm{n}_{\mathrm{p}}$ the number of polymorphic fragments and $n_{m}$ the number of monomorphic fragments. RP was calculated according to Prevost and Wilkinson (1999):

$R P=\sum I_{b}$

where $I_{b}$ represents fragment informativeness. The $I_{b}$ can be represented into a $0-1$ scale by the following formula:

$\mathrm{I}_{\mathrm{b}}=1-\left(2 \times \mid 0.5-\mathrm{f}_{\mathrm{i}}\right)$

Genetic distances among accessions were estimated according to the Dice's coefficient with DARwin 6.0 (PERRIER; JACQUEMOUD-COLLET, 2015). Then, the dissimilarity matrix with data from both marker systems (AFLP + ISSR) was obtained and used to generate a phenogram with the neighbor-joining algorithm (bootstrap with 3,000 replications). Afterwards, an analysis of molecular variance (AMOVA) with 1,000 replications was calculated in order to analyze diversity levels among and within the obtained groups of the phenetic analysis by using Arlequin 3.5 (EXCOFFIER; LISCHER, 2010). Additionally, the polymorphic fragments obtained were categorized according to their respective frequency intervals: Rare Fragments $(0.05<\mathrm{RF}<0.20)$, Frequent Fragments $(0.20 \leq \mathrm{FF} \leq 0.80)$ and Common Fragments $(0.80<\mathrm{CF}<0.95)$. For the variable fragments that were counted as monomorphic, the following categories were determined: Unique Fragments $(\mathrm{UF} \leq 0.05)$ and Shared Fragments $(\mathrm{SF} \geq 0.95)$.

\section{Results and Discussion}

By applying the 21 AFLP primer combinations, 640 markers were generated, from which 278 (43.4\%) were present in 5-95\% of the accessions, thus being considered as polymorphic (Table 2). On the other hand, despite a lower number of generated fragments, the ISSR markers were substantially more polymorphic. A total of 264 markers were obtained from the 21 ISSR primers, from which 187 were polymorphic (70.8\%; Table 3). Taking into 
Table 3. Features and polymorphism level of oligonucleotides used for generating ISSR polymorphisms among 27 castor genotypes.

\begin{tabular}{|c|c|c|c|c|c|c|c|c|c|c|c|c|}
\hline $\begin{array}{l}\text { UBC Primers } \\
\text { [repeats] }^{1}\end{array}$ & $\mathbf{T} a\left({ }^{\circ} \mathbf{C}\right)^{2}$ & $\mathbf{T N F}^{3}$ & $\mathbf{N P F}^{4}$ & $f_{p}(\%)^{5}$ & NUF $^{6}$ & $\mathbf{N R F}^{7}$ & NFF $^{8}$ & $\mathbf{N C F}^{9}$ & NSE $^{10}$ & $P I^{11}$ & $\mathbf{M I}^{12}$ & $\mathbf{R P}^{13}$ \\
\hline $807\left[(\mathbf{A G})_{8} \mathrm{~T}\right]$ & 50.4 & 18 & 10 & 55.6 & $\mathbf{0}$ & $\mathbf{0}$ & 6 & 4 & 3 & 0.201 & 1.884 & 5.556 \\
\hline $810\left[(\mathbf{G A})_{8} T\right]$ & 50.4 & 12 & 6 & 50.0 & 1 & $\mathbf{0}$ & 3 & 3 & 0 & 0.165 & 1.358 & 2.593 \\
\hline $812\left[(\mathbf{G A})_{8} \mathbf{A}\right]$ & 50.4 & 12 & 10 & 83.3 & $\mathbf{0}$ & $\mathbf{0}$ & 9 & 1 & $\mathbf{0}$ & 0.342 & 4.697 & 6.296 \\
\hline $817\left[(\mathrm{CA})_{8} \mathrm{~A}\right]$ & 50.0 & 11 & 9 & 81.8 & $\mathbf{0}$ & $\mathbf{0}$ & 5 & 4 & $\mathbf{0}$ & 0.293 & 3.953 & 4.815 \\
\hline $824\left[(\mathrm{TC})_{8} \mathrm{G}\right]$ & 52.0 & 16 & 16 & 100 & $\mathbf{0}$ & 4 & 9 & 3 & $\mathbf{0}$ & 0.308 & 5.076 & 7.259 \\
\hline $825\left[(\mathrm{AC})_{8} \mathrm{~T}\right]$ & 50.4 & 14 & 11 & 78.6 & 0 & $\mathbf{0}$ & 7 & 4 & 0 & 0.267 & 3.460 & 5.481 \\
\hline $826\left[(\mathrm{AC})_{8} \mathrm{C}\right]$ & 52.8 & 23 & 20 & 87.0 & 2 & 13 & 3 & 4 & $\mathbf{0}$ & 0.209 & 2.995 & 6.370 \\
\hline $827\left[(\mathrm{AC})_{8} \mathrm{G}\right]$ & 52.8 & 23 & 18 & 78.3 & 2 & 6 & 8 & 4 & 0 & 0.267 & 3.447 & 8.741 \\
\hline $840\left[(\mathrm{GA})_{8} \mathrm{YT}\right]$ & 52.8 & 11 & 6 & 54.5 & 1 & 2 & $\mathbf{0}$ & 4 & $\mathbf{0}$ & 0.128 & 1.149 & 1.630 \\
\hline $841\left[(\mathrm{GA})_{8} \mathrm{YC}\right]$ & 52.0 & 15 & 10 & 73.3 & 2 & 2 & 5 & 3 & 0 & 0.208 & 2.286 & 4.148 \\
\hline $855\left[(\mathrm{AC})_{8} \mathrm{YT}\right]$ & 52.0 & 25 & 19 & 76.0 & 3 & 6 & 9 & 4 & $\mathbf{0}$ & 0.267 & 3.350 & 9.556 \\
\hline $868\left[\mathrm{GAA}_{6}\right]$ & 50.0 & 14 & 11 & 78.6 & 0 & 2 & 4 & 5 & 2 & 0.247 & 3.201 & 4.667 \\
\hline $879\left[\mathrm{CTTCA}_{5}\right]$ & 50.4 & 14 & 9 & 64.3 & 1 & $\mathbf{0}$ & 6 & 3 & $\mathbf{0}$ & 0.212 & 2.249 & 4.074 \\
\hline $887\left[\mathrm{DVD}(\mathrm{TC})_{7}\right]$ & 52.0 & 18 & 9 & 50.0 & 2 & 3 & 5 & 1 & 5 & 0.209 & 1.720 & 5.704 \\
\hline $888\left[\mathrm{BDB}(\mathrm{CA})_{7}\right]$ & 52.0 & 25 & 16 & 64.0 & 2 & 4 & 3 & 9 & 3 & 0.168 & 1.775 & $\mathbf{5 . 0 3 7}$ \\
\hline $891\left[\mathrm{HVH}(\mathrm{GT})_{7}\right]$ & 52.0 & 13 & 7 & 53.8 & $\mathbf{0}$ & 1 & 6 & 0 & 1 & 0.209 & 1.860 & 4.148 \\
\hline Total & - & 264 & 187 & 70.8 & 16 & 43 & 88 & 56 & 14 & - & - & - \\
\hline
\end{tabular}

${ }^{1}$ Degenerated bases: B (C, G or T), D (A, G or T), H (A, C or T), V (A, C or G) and Y (C or T). ${ }^{2}$ Annealing temperature. ${ }^{3}$ Total number of fragments. ${ }^{4}$ Number of polymorphic fragments. ${ }^{5}$ Frequency of polymorphic fragments. ${ }^{6}$ Number of unique fragments. ${ }^{7}$ Number of rare fragments. ${ }^{8} \mathrm{Number}$ of frequent fragments. ${ }^{9} \mathrm{Number}$ of common fragments. ${ }^{10}$ Number of shared fragments. ${ }^{11}$ Polymorphism information content. ${ }^{12}$ Marker index. ${ }^{13}$ Resolving power.

account both marker systems (AFLP + ISSR), out of 904 amplified fragments, 465 polymorphic markers were obtained (51.4\%).

The total number of amplified fragments (TNF) by each AFLP primer pairs ranged from eight (E-ACA/M-CAC) to 63 (E-ACG/M-CAC), and a mean of 30.5 markers by primer combination (Table 2). Regarding the ISSR markers, the mean TNF was 16.9, ranging from 11 (UBC-817) to 25 (UBC-855 and UBC-888), as showed in Table 3.

The high levels of polymorphism for both AFLP and ISSR in this analysis indicate the great potential in applying these marker systems for genetic differentiation among castor accessions (ALLAN et al., 2008; GAJERA et al., 2010; PECINA-QUINTERO et al., 2013), as it has been reported for physic nut, another Euphorbiaceae crop (TATIKONDA et al., 2009; GRATIVOL et al., 2011). Besides being as low-cost as RAPD, ISSR markers are highly recommended due to its great reproducibility and ease to be applied in genetic improvement programs (WEISING et al., 2005). Even with a considerably lower number of amplified fragments, the ISSR primers accessed a greater proportion of polymorphic characters than AFLP, as previously reported for common bean (SVETLEVA et al., 2006). However, the opposite situation generally occurs, as reported for Tribulus terrestris L. (SARWAT; DAS; SRIVASTAVA, 2008). Thus, the application of AFLP markers is highly recommended in genetic diversity analysis due to the great amount of generated fragments in only one PCR, in addition to the ability to access different regions of the genome, when compared to ISSR markers (WEISING et al., 2005; NYBOM; WEISING; ROTTER, 2014).
A positive correlation was observed between PIC mean values and frequencies of the marker categories for both AFLP $(r=0.751 ; p=0.144)$ and ISSR markers $(r=0.978 ; p=0.004)$. Consequently, besides being more frequent, the FF markers were the most informative ones $\left(\mathrm{PIC}_{\mathrm{AFLP}}=0.427 ; \mathrm{PIC}_{\mathrm{ISSR}}=0.436\right)$. The PIC values of the polymorphic fragments of both marker systems ranged from 0.137 to 0.499 , although showing different mean values ( 0.296 for AFLP and 0.314 for ISSR). The mean PIC value for AFLP markers (0.121, ranging from 0.014 to 0.226 , for E-ACT/M-CAC and E-ACG/M-CAA, respectively; Table 2) was far below the obtained for ISSR markers $(0.231$, ranging from 0.128 to 0.342 , for UBC- 840 and UBC-812, respectively; Table 3 ).

The obtained values of MI are shown in Tables 2 and 3 for AFLP primer combinations and ISSR primers, respectively. For AFLP markers, the mean MI ranged from 0.021 (E-ACT/M-CAC) to 3.958 (E-ACG/M-CAA) with a mean of 1.755 (Table 2). On the other hand, the mean MI value for ISSR markers was 2.78 , ranging from 1.15 and 5.08 , for UBC-840 and UBC-824, respectively (Table 3). Additionally, a strong positive correlation was observed among PIC and MI values both for AFLP $(r=0.959 ; p<0.0001)$ and ISSR $(r=0.947$; $p<0.0001)$ markers.

The RP values for AFLP markers varied between 0.231 (E-ACA/M-CAC) and 18.231 (E-ACT/M-CTA), with a mean of 5.723 (Table 2). For the ISSR markers, the mean RP value was close to the AFLP markers (5.340), although showing a smaller range of variation (1.630-9.556, for UBC-840 and UBC-855; Table 3). Also regarding the other parameters of 
the AFLP primer combinations, there was a strong positive correlation among MI and RP $(r=0.842 ; p<0.0001)$ values, as well as among RP and PIC $(r=0.831 ; p<0.0001)$ values. On the other hand, for ISSR primers, only a moderate correlation was observed among MI and $\mathrm{RP}(r=0.623 ; p=0.0098)$ values and among RP and PIC ( $r=0.645 ; p=0.007)$ values.

Since PIC values were used to calculate the MI, the strong association between these two indexes was already expected. The RP is a parameter that is considered to be similar to the MI, being strongly correlated to the capacity that a primer (or primer combination) has in differentiating among genotypes (PREVOST; WILKINSON, 1999). Thus, although the mean values of the analyzed parameters (PIC, MI and RP) were lower for AFLP markers, the primer combinations E-ACG/M-CAA, E-ACG/M-CAC, E-AGG/M-CTA and E-ACT/M-CTA were more efficient than any ISSR primer in the identification of accessions.

Some previous analyses reported no correlation between MI and RP (PREVOST; WILKINSON, 1999), or among any of the three indexes (LAURENTIN; KARLOVSKY, 2007).
However, the positive correlation that we have observed among indexes for both AFLP and ISSR validates the applicability of these approaches for choosing the most informative markers to differentiate among castor genotypes. Similarly, Tatikonda et al. (2009) reported a positive correlation among the three indexes for physic nut with AFLP markers, although Grativol et al. (2011) reported a significant correlation only between PIC and MI values with ISSR markers.

In the clustering analysis, the genotypes were distributed in four main groups, although with low bootstrap values for the major clusters (Figure 1). After allowing for the insertion of reticulations in the combined phenogram (AFLP + ISSR) in the software DARwin 6.0 (LS threshold of 2\% and maximum of 100 reticulations), some interactions between nodes from different groups were visualized, thus indicating some degree of introgression among accessions (Figure 1). Only the Group 3, which was composed by seven accessions, did not show any interaction with members of other clusters (Figure 1). In addition, the low value of the fixation index $\left(\mathrm{F}_{\mathrm{st}}=0.108\right)$ obtained in the AMOVA indicated no genetic

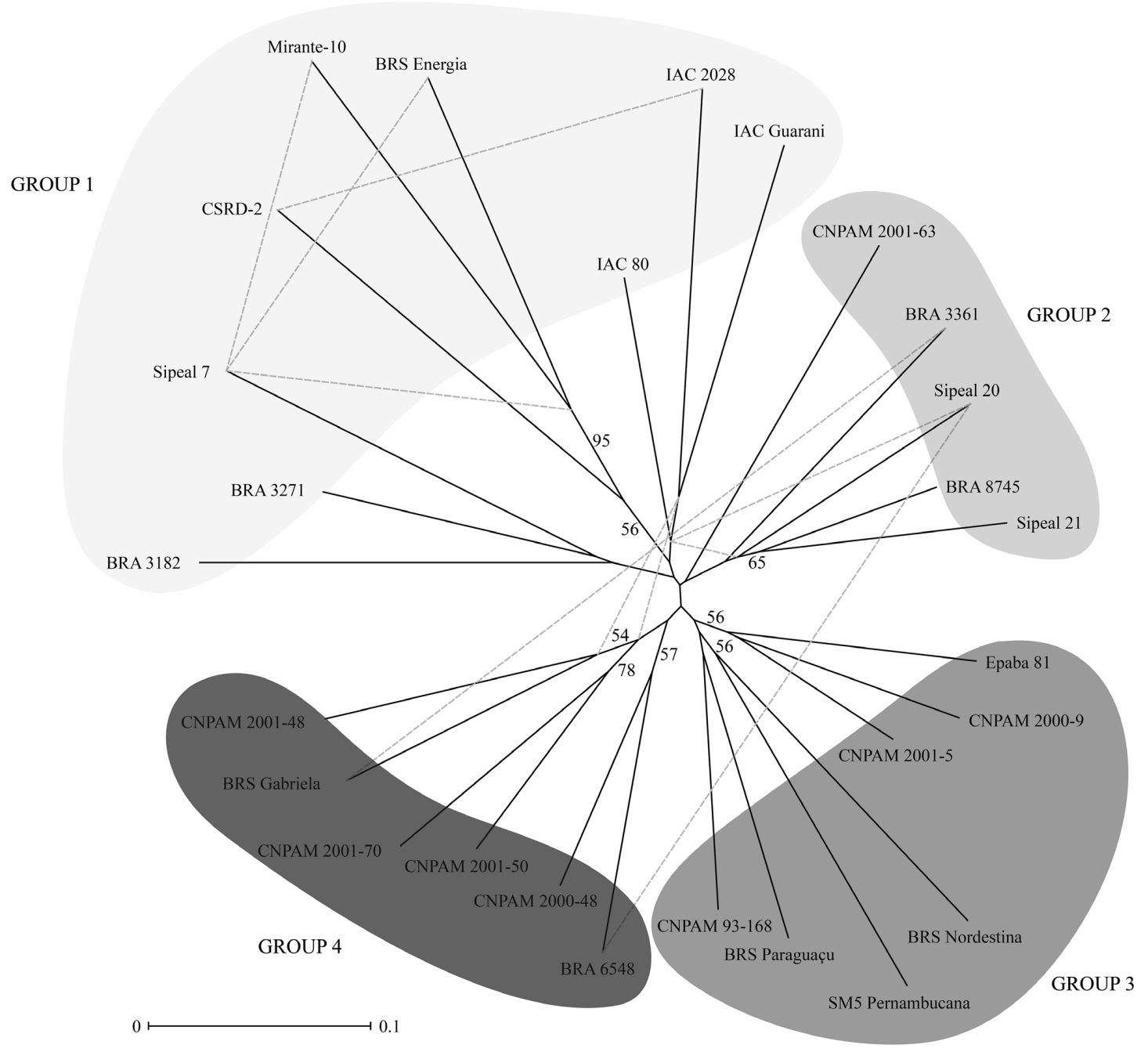

Figure 1. Neighbor-joining clustering analysis among 27 castor genotypes (Dice's coefficient and bootstrap of 3,000 replicates) using AFLP and ISSR markers. Bootstrap values below 50 were not evidenced. 
structuring among the four groups of the phenetic analysis, showing a considerably higher variation within groups (89.2\%) than among groups (10.8\%).

These results are in full agreement with other analyses of this species, which applied different marker systems in a worldwide germplasm collection of castor (AFLP and SSR: ALLAN et al., 2008; nuclear SNPs: FOSTER et al., 2010; chloroplast SNPs: RIVAROLA et al., 2011). Additionally, very low values of observed heterozygosity have been reported among accessions from diverse germplasm banks, by using SSR (ALLAN et al., 2008; BAJAY et al., 2009, 2011; QIU et al., 2010) and SNPs (FOSTER et al., 2010), indicating high levels of endogamy in the species.

In addition, some tendencies could be identified regarding clustering patterns and their association with morphological features. For instance, all accessions that compose Group 3 present similar agronomic traits, such as dehiscent or semi-dehiscent fruits, high size and long cycle. The genotypes BRS Gabriela, CNPAM 2001-48 and CNPAM 2001-50 (Group 4) share the same origin: they all were originated from a selection in the F2 cross between BRS Nordestina and BRS Paraguaçu, which aimed a reduction in plant size and cycle length. The other genotypes from Group 4 (BRA 6548, CNPAM 2000-48 and CNPAM 2000-70) also share similarities in plant sizes, cycle length and semi-dehiscent fruits. Furthermore, almost all genotypes from Group 1 are characterized by indehiscent fruits (except for the accession IAC 80).

\section{Conclusions}

Choosing a marker system to be used is one of the most important steps during the process of characterizing the genetic diversity of a species, especially for crops with a long history of cultivation (as castor, for instance), which generally present a narrow genetic base. The large amount of polymorphic markers for both marker systems employed herein, particularly for the ISSR, corroborate the utility of these markers for castor breeding programs. The discrimination of specific genotypes by unique markers may be very important either for genetic mapping initiatives or for assisted selection of important agronomic traits, such as oil production and resistance to abiotic stress and pathogens, thus resulting in a major objectivity during the improvement of the crop and directing crosses between accessions with contrasting characteristics.

\section{Acknowledgements}

To the following Brazilian agencies, which financially supported this work: Banco do Nordeste do Brasil S/A(BNB), Escritório Técnico de Estudos Econômicos do Nordeste (ETENE), Fundo de Desenvolvimento Científico e Tecnológico (FUNDECI); Conselho Nacional de Desenvolvimento Científico e Tecnológico (CNPq), and Fundação de Amparo à Ciência e Tecnologia do Estado de Pernambuco (FACEPE).

\section{References}

ALLAN, G. et al. Worldwide genotyping of castor bean germplasm (Ricinus communis L.) using AFLPs and SSRs. Genetic Resources and Crop Evolution, Dordrecht, v. 55, p. 365-378, 2008. http:// dx.doi.org/10.1007/s10722-007-9244-3.

ANJANI, K. Castor genetic resources: a primary gene pool for exploitation. Industrial Crops and Products, Amsterdam, v. 35, p. 1-14, 2012. http://dx.doi.org/10.1016/j.indcrop.2011.06.011.

BAJAY, M. M. et al. Development and characterization of microsatellite markers for castor (Ricinus communis L.), an important oleaginous species for biodiesel production. Conservation Genetics Resources, Dordrecht, v. 1, p. 237-239, 2009. http://dx.doi.org/10.1007/ s12686-009-9058-z.

BAJAY, M. M. et al. Development of a novel set of microsatellite markers for castor bean, Ricinus communis (Euphorbiaceae). American Journal of Botany, Saint Louis, v. 98, p. e87-e89, 2011. http://dx.doi.org/10.3732/ajb.1000395.

BORNET, B.; BRANCHARD, M. Nonanchored inter simple sequence repeat (ISSR) markers: reproducible and specific tools for genome fingerprinting. Plant Molecular Biology Reporter, New York, v. 19, p. 209-215, 2001. http://dx.doi.org/10.1007/BF02772892.

CHAN, A. et al. Draft genome sequence of the oilseed species Ricinus communis. Nature Biotechnology, New York, v. 28, p. 951-956, 2010. http://dx.doi.org/10.1038/nbt.1674.

EXCOFFIER, L.; LISCHER, H. E. L. Arlequin suite ver 3.5: a new series of programs to perform population genetics analyses under Linux and Windows. Molecular Ecology Resources, Hoboken, v. 10, p. 564-567, 2010. http://dx.doi.org/10.1111/j.1755-0998.2010.02847.x.

FOSTER, J. T. et al. Single nucleotide polymorphisms for assessing genetic diversity in castor bean (Ricinus communis). BMC Plant Biology, London, v. 10, n. 13, 2010. http://dx.doi.org/10.1186/14712229-10-13.

GAJERA, B. B. et al. Assessment of genetic diversity in castor (Ricinus communis L.) using RAPD and ISSR markers. Industrial Crops and Products, Amsterdam, v. 32, p. 491-498, 2010. http://dx.doi. org/10.1016/j.indcrop.2010.06.021.

GRATIVOL, C. et al. High efficiency and reliability of Inter-Simple Sequence Repeats (ISSR) markers for evaluation of genetic diversity in Brazilian cultivated Jatropha curcas L. accessions. Molecular Biology Reports, Dordrecht, v. 38, p. 4245-4256, 2011. http:// dx.doi.org/10.1007/s11033-010-0547-7.

LAURENTIN, H.; KARLOVSKY, P. AFLP fingerprinting of sesame (Sesamum indicum L.) cultivars: identification, genetic relationship and comparison of AFLP informativeness parameters. Genetic Resources and Crop Evolution, Dordrecht, v. 54, p. 1437-1446, 2007. http://dx.doi.org/10.1007/s10722-006-9128-y.

MACHADO, E. L. et al. Dissimilaridade genética entre cultivares de mamoneira por meio de marcadores RAPD. Pesquisa Agropecuária Brasileira, Brasília, v. 48, p. 342-345, 2013. http://dx.doi.org/10.1590/ S0100-204X2013000300014.

NYBOM, H.; WEISING, K.; ROTTER, B. DNA fingerprinting in botany: past, present, future. Investigative Genetics, London, v. 5, n. 1, 2014. http://dx.doi.org/10.1186/2041-2223-5-1.

OGUNNIYI, D. S. Castor oil: a vital industrial raw material. Bioresource Technology, Oxford, v. 97, p. 1086-1091, 2006. http://dx.doi. org/10.1016/j.biortech.2005.03.028.

OTT, J. Strategies for characterizing highly polymorphic markers in human gene mapping. American Journal of Human Genetics, Cambridge, v. 51, p. 283-290, 1992. 
PAMIDIMARRI, D. V. S.; REDDY, M. P. Phylogeography and molecular diversity analysis of Jatropha curcas L. and the dispersal route revealed by RAPD, AFLP and nrDNA-ITS analysis. Molecular Biology Reports, Dordrecht, v. 41, p. 3225-3234, 2014. http:// dx.doi.org/10.1007/s11033-014-3185-7.

PECINA-QUINTERO, V. et al. Assessing the genetic diversity of castor bean from Chiapas, México using SSR and AFLP markers. Industrial Crops and Products, Amsterdam, v. 41, p. 134-143, 2013. http://dx.doi.org/10.1016/j.indcrop.2012.04.033.

PERRIER, X.; JACQUEMOUD-COLLET, J. P. DARwin 6.0 software. Available from: $<$ http://darwin.cirad.fr/darwin $>$. Access in: 22 Apr. 2015.

PREVOST, A.; WILKINSON, M. J. A new system of comparing PCR primers applied to ISSR fingerprinting of potato cultivars. Theoretical and Applied Genetics, New York, v. 98, p. 107-112, 1999. http://dx.doi.org/10.1007/s001220051046.

QIU, L. et al. Exploiting EST databases for the development and characterization of EST-SSR markers in castor bean (Ricinus communis L.). BMC Plant Biology, London, v. 10, n. 278, 2010. http://dx.doi.org/10.1186/1471-2229-10-278

RIVAROLA, M. et al. Castor bean organelle genome sequencing and worldwide genetic diversity analysis. PLoS One, San Francisco, v. 6, n. e21743, 2011. http://dx.doi.org/10.1371/journal.pone.0021743.

ROLDAN-RUIZ, I. et al. AFLP markers reveal high polymorphic rates in ryegrasses (Lolium spp.). Molecular Breeding, Dordrecht, v. 6, p. 125-134, 2000. http://dx.doi.org/10.1023/A:1009680614564.

SARWAT, M.; DAS, S.; SRIVASTAVA, P. Analysis of genetic diversity through AFLP, SAMPL, ISSR and RAPD markers in Tribulus terrestris, a medicinal herb. Plant Cell Reports, New York, v. 27, p. 519-528, 2008. http://dx.doi.org/10.1007/ s00299-007-0478-5.
SEVERINO, L. S. et al. A review on the challenges for increased production of castor. Agronomy Journal, Madison, v. 104, p. 853-880, 2012. http://dx.doi.org/10.2134/agronj2011.0210.

SVETLEVA, D. et al. Molecular characterization of Phaseolus vulgaris L. genotypes included in Bulgarian collection by ISSR and AFLP analyses. Scientia Horticulturae, Amsterdam, v. 109, p. 198-206, 2006. http://dx.doi.org/10.1016/j.scienta.2006.04.001.

TATIKONDA, L. et al. AFLP-based molecular characterization of an elite germplasm collection of Jatropha curcas L., a biofuel plant. Plant Science, Shannon, v. 176, p. 505-513, 2009. http://dx.doi. org/10.1016/j.plantsci.2009.01.006.

VARSHNEY, R. K. et al. Comparative assessment of EST-SSR, EST-SNP and AFLP markers for evaluation of genetic diversity and conservation of genetic resources using wild, cultivated and elite barleys. Plant Science, Shannon, v. 173, p. 638-649, 2007. http://dx.doi.org/10.1016/j.plantsci.2007.08.010.

VASCONCELOS, S. et al. Molecular markers to access genetic diversity of castor bean: current status and prospects for breeding purposes. In: ABDURAKHMONOV, I. Y. (Ed.). Plant breeding. Rijeka: Intech, 2012. p. 201-222. http://dx.doi.org/10.5772/27144

VOS, P. et al. AFLP: a new technique for DNA fingerprinting. Nucleic Acids Research, Oxford, v. 23, p. 4407-4414, 1995. http://dx.doi. org/10.1093/nar/23.21.4407.

WEISING, K. et al. DNA fingerprinting in plants: principles, methods, and applications. 2nd ed. Boca Raton: CRC Press, 2005. 444 p. 